\title{
An Exploring of Lecturers' Perceptions in Applying Divergent and Convergent Questions in EFL Classroom
}

\author{
Isnaini Eddy Saputro \\ \{isnaini1712@gmail.com\} \\ English Education Study Program \\ Muhammadiyah Sorong University of Education
}

\begin{abstract}
The main aim of learning language for the students is how they build up interaction well with the classmate and the lecturers in the classroom. The researcher is wondering whether questions are still required to invite the students speak up in the classroom or not. The researcher applied a descriptive qualitative method to answer research questions in this research. The participants of this research were two lecturers of English Education program. The data was taken by conducting classroom observation and interview. The findings of the research showed that the kinds of questions used by the lecturers were divergent and convergent questions to help the students to think and to get the students' attention of the material. The using those questions are able to build up interaction with the students. Two combinations of question were mentioned as leading question.
\end{abstract}

Keywords: Lecturers' Perception, Divergent Question, Convergent Question

\section{Introduction}

As an English lecturer, teaching by questioning is a task to invite the students to get understanding from the concept of material taught by the lecturer. The lecturer can involve the students to recall the content of the topic by giving brainstorming, giving information, giving explanations and giving questions by concept of teacher talk. It will influence students' target language as a foreign language. It will practice the students to respond speaking loudly in the classroom. White and Lightbown's (1984) found that lecturers asked nearly 200 questions per class period. Thus, the lecturer has a reason to use the question to know whether the students understand or not, whether the students follow her class or not.

Conducting teaching in the classroom to practice students speaking ability should be based on questioning the students. That has stated by Al- Darwish (2012) EFL lecturers use questions in the classroom to achieve these interconnected goals. Question-asking is a didactic mode of instruction that can be described as "teaching by telling". Learners' minds were improved through the acquisition of organized knowledge by learning grammar and vocabulary. It means that conducting teaching in the classroom should be based on questioning the students. Asking the student is needed to be applied for understanding the objectives of education attached in the lesson plan. Many reasons make the students passive in 
the classroom such as no interaction between the lecturer and the students. The lecturers do not involve the students in learning to express their idea or opinion. This problem looks that how the teacher solve this issue. When the researcher conducted preliminary study, the researcher concluded that to solve those reasons, the lecturers must give questions starting from simple questions and continued it with the types of inquiry which are assigned to students to ask their reason, opinion and provide the perspectives of a new idea about something related to the topic. Mahmud (2015) said that since lecturers and students are essential actors in the class, the use of questions is believed to be crucial as a bridge in finding the gap of mind in the learning and teaching process. The purpose of questions is supposed to be a creative medium in encouraging students' activities in the class

Question will bring the students to learn as fun as possible because they can express their thought such as idea, opinion, suggestion and comment. Some of students also need to solve in learning process. Cotton (2001) said that questioning is second only to lecturing in popularity as a teaching method and that classroom lecturers spend anywhere from thirty-five to fifty percent of their instructional time conducting questioning sessions. Thus, lecturer must provide some questions to 12 brainstorm the students to predict outcomes and to invite learners to argue opinions. Types of questions that can be used to invite students to active in the classroom are such as divergent and3 convergent. Why the researcher directly focuses on those questions? because those will help the students to express their main. There is type of question that only needs students to say agreement "yes or no" and there is a question that needs students to reveal their mind. Ozturk (2016) assumed that convergent questions mostly require short answers or yes/no, and learners are not occupied with higher mental functions than divergent questions are the opposite of convergent questions. They encourage students to provide their own information rather than to recall previously presented information.

In this occasion, the researcher wanted to observe the lecturers' perceptions when they used questions in the classroom to build interaction by explaining the lesson. This research focused to see the lecturers' reason to raise questions in the classroom. Moreover, the researcher intended to conduct this research because the researcher wanted to know whether the students still required the questioning in teaching contemporary or not.

\section{Literature Review}

Erdogan and Campbell (2008) studied about "Teacher Questioning and Interaction Patterns in Classrooms Facilitated with Differing Levels of Constructivist". They compared that teaching used HLCTP to ask open-ended question is more significant than teaching used closed-ended questions and task-oriented questions. The student preferred closed-ended question to complete investigations but to use open-ended question must be obligated for the teacher to be used in teaching learning process.

Kim (2015) conducted a research about "an Analysis of Teacher Question Types in Inquiry-Based Classroom and Traditional Classroom Settings". In a traditional class, teachers

${ }^{1}$ Brock (1986) contended that referential questions increase the amount of learner output

2 Erlinda and Dewi (2014) procedural, convergent, and divergent questions as suggested by Richards \& Lockhart (1996). 
always use closed-ended question to engage with the students. Unfortunately the students feel pressure because they want to express their idea but in this case the teacher just wants to ask the specific answers. Hence, the lecturers must encourage the question that provides students' opinion and reason in discussion. The advantage in using open-ended question is directly related to the frequency of student higher-order thinking responses. Higher-order thinking reflective to Bloom's revised taxonomy and argumentation components.

Brock (1986) contended that referential questions increase the amount of learner output; therefore, an increased use of referential questions by lecturers may create discourse which can produce a flow of information from students to the teacher.

The research about "Questioning Powers of the Students in the Class" by Mahmud (2015) stressed about the types of questions produced by the students and to describe their perspectives on their questioning powers. Students mostly produced referential questions, which need more explanation and clarification or judgments from the answerers. It can be proved that questions have very important support in the classroom interaction as one way to initiate the collaboration between lecturers and students.

\subsection{Types of direct question}

Erlinda and Dewi (2014) said that basically questions are grouped into three categories in terms of the purpose of questions in classrooms. They include procedural, convergent, and divergent questions as suggested by Richards \& Lockhart (1996).

4Ozturk (2016) said that procedural questions are related to the procedures in the classroom setting, and they have nothing to do with the content of the lesson. "Can you see what I have written on the board?", "How much time do you need to finish this task?" are the examples included in this group. Procedural questions do not involve engaging the students, making the students' comprehension easier or promoting interaction in the classroom. Convergent questions encourage similar student response or responses which focus on a central theme. They do not usually require students to engage in higher-level thinking to come up with an answer but often focus on the recall of previously presented information. Examples of convergent questions contain "How many of you read books?", "Do you read books every day?".

Anderson (2012) said that divergent questions encourage students to respond with a longer and more complex answer. For example, if the teacher asks a student to analyze why a character from a book behaves in a certain way Ozturk (2016) they encourage students to provide their own information rather than to recall previously presented information.

\subsection{Reason for Asking Questions}

Floyd (1960) developed a study with 40 elementary lecturers and found that these lecturers asked 93 percent of all classroom questions. Bearing in mind that lecturers spend a large percentage of their communication time asking questions it is pertinent to ask: why do lecturers ask questions? What are the functions of lecturers' questions? Lecturers use questioning fundamentally to check understanding and knowledge to aid teaching, to diagnose students' difficulties, to recall facts, to test knowledge, to direct attention and to maintain control.

\footnotetext{
${ }^{3}$ Swan (2008) asked questions for many possible reasons:
} 
Albergeria-Almeida (2010) said other functions associated to lecturers' questioning such as encouraging students to think, arousing interest and curiosity, developing students' reflection and stimulation students to ask questions of their own are not frequently found on classroom questioning.

Vebriyanto in Richard and Lockhart (2015) stated that there are some reasons why questions are widely used by lecturers as teaching technique. First, questions stimulate and maintain students' interest. Second, they encourage students to think and focus on the content of the lesson. Third, they enable a teacher to clarify what a student has said. Fourth, they enable a teacher to elicit particular structures or vocabulary items. Fifth, they enable lecturers to check students' understanding. Sixth, they (questions) encourage student participation in a lesson.

The research from Long and Sato (1983) and Nunan (1987) found that lecturers ask more display questions that require only short, restricted pupil response. The implications behind display or closed questions are that such questions do not reflect genuine communication, encourage only short, restricted responses and that their only purpose appears to be to get students to display knowledge already known to the teacher and recently acquired (in the classroom) by the students. Referential or open questions, on the other hand, are questions that are not factual or text-embedded but those that invite students to draw answers from their own experiences and viewpoints.

Swan (2008) asked questions for many possible reasons:

a. To interest, engage and challenge;

b. To assess prior knowledge and understanding;

c. To stimulate recall, in order to create new understanding and meaning;

d. To focus thinking on the most important concepts and issues;

e. To help students extend their thinking from the factual to the analytical;

f. To promote reasoning, problem solving, evaluation and the formation of hypotheses;

g. To promote students' thinking about the way they have learned;

h. To help students to see connections.

\section{Research Design}

This research was a descriptive qualitative design to investigate, to receive, and to interpret the data to see the lecturers' perception in applying divergent and convergent questions in EFL classroom. Heigham \& Croker (2009) said qualitative research entails collecting primarily textual data and examining it using interpretive analysis. In this research, the researcher applied discourse analysis as an approach to analyze the lecturers' perceptions in applying questions in the classroom to get the data description. The researcher applied the purposive sampling technique in getting data because the subjects of data sources need special consideration. The subjects of this research were two English lecturers to be interviewed to answer in completing the issue. The instruments of this research were observation and interview. The researcher used observation checklist, voice recording and video recording to collect the data for classroom observation and interview. The researcher used qualitative to analyze the data from Miles et al (2014) such as to collect, display, select and conclude the data to reveal the students' behavior in EFL classroom. 


\section{Findings And Discussion}

\subsection{Reason for Questions}

Based on the issue above, this study aimed to find out the reasons for lecturers in using convergent and divergent during the teaching process in the EFL classroom. Furthermore, the data were taken by the researcher by interviewed two lecturers who taught in two places at Graduate level of the State University of Makassar and Undergraduate level of the State University of Makassar. During the interviewing, the researcher recorded the whole of the explanation of the lecturers. The result of lecturers' interview shows the use of the questions in the classroom talks about classroom management. Classroom management includes how the interaction happens between the lecturer and the students. Then, it is ordered to make the students focus on the lecturers' utterance. Moreover, types of question used by the lecturer in the classroom indeed have the function itself. They are to help the students' thinking so that they can speak up to convey their ideas or answer the questions, to know the students' cognitive development through stimulation, to make the classroom situation alive in term of interaction and it is a part of lecturer talk.

Indeed, the use of convergent and divergent questions in the classroom is the point to see or to check students' understanding. To make the students understand, the lecturer would help the students to think firstly through the questions that were used in the teaching process. The data were shown in the following.

\section{Extract 1: Asking the lecturers' opinion about the learning process}

The researcher asked about the lecturer's opinion of students' responding about their ability in teaching in the classroom.

R : (...) what do you think about students responding toward your ability in using English language when you teach them. Whether the students also get your meaning or they still look confuse?

L1 : a(-) ok a(--) speaking when I used English most of the time the students especially undergraduate students seem to be confused but it doesn't matter because I can help them by paraphrasing that connection and by checking their understanding by asking question and that's why I like to ask question because I can see whether the students understand by answering the question. not only the question that "do you understand?" because I am sure that such as kind the question will be answered "yes mom,",

The extract above indicates that teaching English in EFL classroom does not only reveal the material but also make the students understand with the meaningful explanation. A way to explain well to students' understanding is by using questions to involve them to think and to interact with the lecturers by answering the questions. The lecturer also used paraphrased in giving direct questions to assess students' understanding. Questions intended as the long answer or their judgment and perceptive in responding the question. The short question is also required, but it is just for exploratory of process learning itself.

\section{Extract 2: Lecturers' perception about students' ability in understanding}

R : :... here a(-) I want to know about your opinion how the students' respond toward your ability in using English language whether they feel difficult or not?

L2 : that's very difficult question!!. Some students may respond quickly and some may not respond quickly yet because they have different ability among them. For those 
who respond quickly may be they have good understanding the question and instruction and for those are not maybe they are not focus, they have problem for example or perhaps they don't understand instruction.

This extract above indicates the lecturer's perception of students' response to the lecturer's ability in using English in the teaching process. He said that it depended on students' responses toward questions in teaching and learning process. Not all the students were the same focusing on instruction. The students understanding on the lecturer's utterance depended on their ability in understanding instruction. Instruction in lecturer talk consists of giving explanation, direction, correction, asking question and answering question. In this case, some students did not focus on the lecturers' questions in teaching process. That's why some of them preferred to choose group discussion than the direct questions in the classroom even the students suggested to combine the strategy.

\section{Extract 3: Lecturers' way to check students' understanding}

The researcher asked the lecturer about the way to know the students' understanding.

$\mathrm{R} \quad$ : .... how do you know to measure students understanding? The last time you said that you give question to them, is there another strategy?

L1 : a(--) ok asking confirmation, hmm no,no, ok asking comprehension, question yes and sometimes I asked the students to restated what I have explained including conclusion or just to ask them "ok would you say, what you understand about the material that I have presented?" and then another way to make them show me, what, I just instruct them a(-) I just instruct them to say which part they don't understand

The extract above indicates lecturer's statement that she uses the question to check the students' understanding. She asked the students about the opinion something related to the topic. It intends to know whether the students can restate or give an idea by their understanding. She always focused on the instruction that she used because instruction could determine what the students would respond toward what the lecturers instructed to them. Question was one of the instruction forms. In this case, the lecturer uses the direct questions in teaching process to restate and stimulate a new understanding and a meaning.

\section{Extract 4: Lecturers' purpose in using types of question in teaching}

$\mathrm{R} \quad$ : so, a(-) how is your way to make students focus on the class because here I saw about the kinds of questions that you used, the first when you enter in the classroom, you make the small talk using the procedural question. The first you ask about the atmosphere in the classroom because the class was very hot and after that you used the, what is, opening, no, open ended question. Actually I don't know what is the aim when you used the, procedural and after that open ended question? : I usually start with the question because the question helps them to think for adult learners. So, one of the good way to start the learning is to ask them question. So, they can think and their cognitive can be active, so when we ask question.

The extract above shows that the lecturer agrees if he always uses the question as a bridge to know and to see the students' development in term of cognition. He always used question in the beginning at teaching process. It can be seen that the lecturer uses the question to make the students interested, engage and challenge in the learning process directly. 


\section{Extract 5: Lecturers' purpose in using types of question in teaching}

$\mathrm{R}$ : Yeah ok, you said that you always used question, you always used question so which one do you use higher level question or lower level question?

L1 : well for low level students@@ mostly, mostly just to lead them to get the material a(--) well I didn't really identify the question is low level or high level but it depends, it depends on the mood, depends on classroom situation and also depends on the material.

$\mathrm{R} \quad$ : because I found in your data you mostly used referential question, it means that you want to ask students' opinion you want to invite the students to critical thinking, why you must use those questions?

L1 : because they are university students, yah so I think they need to think more critically and "yah that's the point the material that they need to understand. They should be told clearly, logically, and also because I teach language philosophy so $<$ XwordX $>$.

The extract above reveals that the lecturer cannot determine about high or lower level question. She uses the question as well as the situation in the classroom, as well as the students' feeling at the time. It depends on the material. Moreover, she used the question because she was aware that she taught the students at university. The questions were used to invite them to think logically. Thus, the students could extend their thinking process from the factual to the analytical issue.

\section{Extract 6}

$\mathrm{R} \quad: \quad \ldots$ so you agree if the question, question is one of the important strategy to measure students' understanding or you have,

L2 : not only to measure understanding is way about the measure, this is about a(-) how to help them to think. Understanding is different of thinking because once they think, it is easy for anything. So this is to help established critical thinking rather than to measure understanding yeah, because all the question is about help them to think. Asked them to think, it's not about right or wrongs the answer but it's about help to think, update their mind so that's most important thing in university level. That's why we never start with game. It is not good for the game. It is good for teaching kids for example because if we asked them to understanding will ask them to memorize. That's not good for memorization.

The extract above states that the lecturer uses the question to help the students to think not only to understand but also to involve the students in thinking process of learning. In this case, the students were asked to think freely. Although the students' answer was right or wrong, it could not be judged that they could not think well, but it has succeeded to help them think. Thus, the use of question does not only know students' understanding or not, but it is essential to help the students to think. When the students were thinking, they were creating the meaning by themselves and they also understand the material by themselves through thinking.

\subsection{The Reasons for Question}

Based on the observation in this study, the reason of lecturers in using those questions in the classroom could create teaching effectively. There was an interaction between the lecturers and the students. Besides that, the lecturers gave a chance to students to be more active in providing new information while the lecturers corrected. When the lecturers used questions in the classroom, some reasons arose such as the students were interested and motivated to 
respond what the lecturers asked. The students were effectively to recall the material and to feel free in giving their opinion, and the students could argue opinions as well as their prior knowledge. Most of the students agreed to learn with the lecturers question although some of their answering was wrong or right. They have tried to create new meaning, and the lecturers gave correction. Erdogan and Campbell (2008) the student preferred closed-ended question to complete investigations but to use open-ended question must be obligated for the teacher to be used in teaching learning process.

The lecturers agreed that question helped the students to think, especially for adult learners. So, it was one of the good ways to start the learning to ask them the question. They could think, and their cognitive could be active when the lecturers asked the question. Kim (2015) revealed that lecturers always use closed-ended question to engage with the students. Unfortunately the students feel pressure because they want to express their idea but in this case the teacher just wants to ask the specific answers. In this research, the lecturer gave the statement that question is not only to measure understanding, but it was also to help them to think.

Besides that, it was a way to encourage personal connection to the content. The understanding was a different way of thinking because once they think, it was easy for anything. So, it was established to help critical thinking rather than to measure understanding because all questions helped them to think and asked them to think. It was not about right or wrong answer, but it was about a way to update their mind so that it was the most important thing in the university level. Brock (1986) contended that referential questions increase the amount of learner output. That's why during this research, the lecturers never started with the game. It was not good for the game to improve lesson effectiveness and to get the students thinking. It was good for teaching the kids. If the lecturers asked them to understand, it meant that the lecturers asked them to memorize. Learning language was not good for memorization. It would be good if the lecturer involved the students to take their role in discussion part such as communication with each other and share their idea. Thus, there was an outcome for the students in learning language. It was line with Mahmud (2015) revealed that questions have very important support in the classroom interaction as one way to initiate the collaboration between lecturers and students.

\section{Conclusions}

The conclusion is drawn based on the research questions of the research. It relates to the reasons of the lecturers using direct questions in the teaching process. In this research, the lecturers always use divergent question to elicit the interaction with the students. The divergent question consists of the referential, non-referential and open-ended question. These have the function to elicit students' opinion, to invite students to think critically because the lecturers prefer more to use these type questions depending on students' level education. Moreover, the researcher stressed that divergent question can invite the students to be more active in giving output in language learning. Although they have tried to answer by using Indonesia language, they have tried to express their variation ideas without avoiding the convergent question as display question and closed-ended question. The researcher observes that the convergent questions that are used by the lecturers help to elicit the students' interaction. Firstly it can be used to attract students' attention, and after that, the lecturers prompt to use the divergent question to see whether the students' are following the class or 
not. In this research, when the lecturers used two type questions in a section to get the students' attention, it means that the lecturers are trying to combine these questions that are mentioned as leading question. Leading question is a question formed by two type of question to prompt the desired answer from the students. It makes the students' active and motivates the students.

\section{References}

[1] Albergaria-Almeida, P. (2010). Classroom questioning: teachers' perceptions and practices. Procedia-Social and Behavioral Sciences, 2(2), 305-309.

[2] Al-Darwish, S. (2012). The role of teacher questions and the Socratic method In EFL classrooms in Kuwait. World Journal of Education, 2(4), 76.

[3] Andersson, S. (2012). Teacher and student questions in the EFL classroom: A study of gender and interaction in three Swedish classes.

[4] Brock, C. A. (1986). The effects of referential questions on ESL classroom discourse. TESOL quarterly, 20(1), 47-59.

[5] Cotton, K. (2001). Classroom questioning. School improvement research series, 3.

[6] Erdogan, I., \& Campbell, T. (2008). Teacher questioning and interaction patterns in classrooms facilitated with differing levels of constructivist teaching practices. International Journal of Science Education, 30(14), 1891-1914.

[7] Erlinda, R., \& Dewi, S. R. (2016). Teacher's Questions in EFL Classroom. Ta'dib, 17(2), 177188.

[8] Floyd, W. D. (1960). An analysis of the oral questioning activities in selected Colorado classrooms. Ph.D. Thesis. Colorado: Colorado State College.

[9] Heigham, J., \& Croker, R. A. (2009). Qualitative Research in Applied Linguistics; A Practical Introduction. Houndmills, Basingstoke, Hampshire, England: Palgrave Macmillan.

[10] Kim, S. (2015). An analysis of teacher question types in inquiry-based classroom and traditional classroom settings. The University of Iowa.

[11] Long, M. H., \& Sato, C. J. (1983). Classroom foreigner talk discourse: Forms and functions of teachers' questions. Classroom oriented research in second language acquisition, 268-285.

[12] Mahmud, M. (2015). Questioning Powers of the Students in the Class. Vol. 6, No. 1, pp. 111116

[13] Miles, M. B., Huberman, A. M., \& Saldana J. (2014). Qualitative Data Analysis: A Methods Sourcebook (3rd edition). USA: Sage Publications, Inc.

[14] Nunan, D. (1987). Communicative language teaching: Making it work. ELT journal, 41(2), 136145.

[15] Öztürk2. O. A. (2016). Types of Questions Used in EFL Classrooms: A Reflective Study on A Turkish Efl Teacher's Practices1. Turkey. Çukurova University: International Journal of Language Academy.

[16] Richards, J. C. \& Lockhart, C. (1996). Reflective teaching in second language classrooms. Cambridge, England: Cambridge University Press.

[17] Swan, M., \& Pead, D. (2008). Professional development resources. Bowland Maths Key Stage 3, Bowland Charitable Trust.

[18] Vebriyanto, A, D. (2015). Teacher's questions in EFL Classroom interaction. Journal Vision, Volume 4 Number 2.

[19] White, J., \& Lightbown, P. (1984). Asking and answering in ESL classes. Canadian. 